\title{
Environmental Characteristics of Clays and Clay Mineral Deposits
}

Clays and clay minerals have been mined since the Stone Age; today they are among the most important minerals used by manufacturing and environmental industries. The U.S. Geological Survey (USGS) supports studies of the properties of clays, the mechanisms of clay formation, and the behavior of clays during weathering. These studies can tell us how and where these minerals form and provide industry and land-planning agencies with the information necessary to decide how and where clay and clay mineral deposits (fig. 1) can be developed safely with minimal effects on the environment.

The term "clay" is applied both to materials having a particle size of less than 2 micrometers $(25,400$ micrometers $=1$ inch $)$ and to the family of minerals that has similar chemical compositions and common crystal structural characteristics (Velde, 1995) described in the next section. Clay minerals have a wide range of particle sizes from 10's of angstroms to millimeters. (An angstrom (A) is a unit of measure at the scale of atoms.) Thus, clays may be composed of mixtures of finer grained clay minerals and clay-sized crystals of other minerals such as quartz, carbonate, and metal oxides. Clays and clay minerals are found mainly on or near the surface of the Earth.

\section{Physical and Chemical Properties of Clays}

The characterististics common to all clay minerals derive from their chemical composition, layered structure, and size. Clay minerals all have a great affinity for water. Some swell easily and may double in thickness when wet. Most have the ability to soak up ions (electrically charged atoms and molecules) from a solution and release the ions later when conditions change.

Water molecules are strongly attracted to clay mineral surfaces. When a little clay is added to water, a slurry forms because the clay distributes itself evenly throughout the water. This property of clay is used by the paint industry to disperse pigment (color) evenly throughout a paint. Without clay to act as a carrier, it would be difficult to evenly mix the paint base and color pigment. A mixture of a lot of clay and a little water results in a mud that can be shaped and dried to form a relatively rigid solid. This property

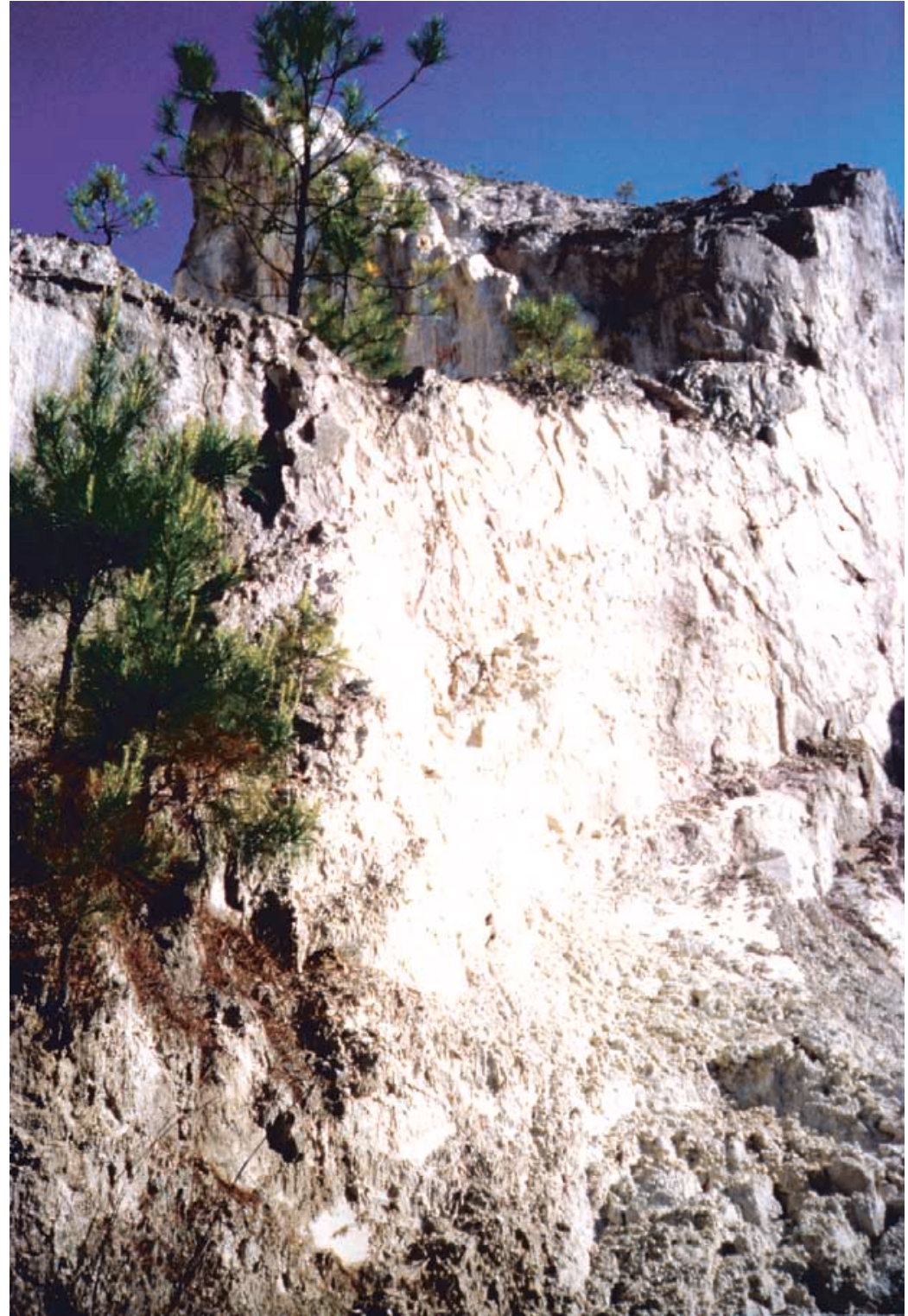

Figure 1. Massive kaolinite deposits at the Hilltop pit, Lancaster County, South Carolina; the clays formed by the hydrothermal alteration and weathering of crystal tuff. Pine tree in the foreground is about 2 meters in height.

is exploited by potters and the ceramics industry to produce plates, cups, bowls, pipes, and so on. Environmental industries use both these properties to produce homogeneous liners for containment of waste.

The process by which some clay minerals swell when they take up water is reversible. Swelling clay expands or contracts in response to changes in environmental factors (wet and dry conditions, temperature). Hydration and dehydration can vary the thickness of a single clay particle by almost 100 percent (for example, a $10 \AA$-thick clay mineral can expand to $19.5 \AA$ in water (Velde, 1995). Houses, offices, schools, and factories built on soils containing swelling clays may be subject to structural damage caused by seasonal swelling of the clay portion of the soil. 
Another important property of clay minerals, the ability to exchange ions, relates to the charged surface of clay minerals. Ions can be attracted to the surface of a clay particle or taken up within the structure of these minerals. The property of clay minerals that causes ions in solution to be fixed on clay surfaces or within internal sites applies to all types of ions, including organic molecules like pesticides. Clays can be an important vehicle for transporting and widely dispersing contaminants from one area to another.

\section{How and Where Clays and Clay Deposits Form}

Clays and clay minerals occur under a fairly limited range of geologic conditions. The environments of formation include soil horizons, continental and marine sediments, geothermal fields, volcanic deposits, and weathering rock formations. Most clay minerals form where rocks are in contact with water, air, or steam. Examples of these situations include weathering boulders on a hillside, sediments on sea or lake bottoms, deeply buried sediments containing pore water, and rocks in contact with water heated by magma (molten rock). All of these environments may cause the formation of clay minerals from preexisting minerals. Extensive alteration of rocks to clay minerals can produce relatively pure clay deposits that are of economic interest (for example, bentonites-primarily montmorillonite - used for drilling muds and clays used in ceramics).

\section{Erosion}

The transport and deposition of clays and clay minerals produced by eroding older continental and marine rocks and soils are important parts of the cycle that forms sedimentary rocks. The ancient sedimentary rock record is composed of about 70 percent mudstones (which contain about 50 percent clay-sized fragments) and shales (which are coarser than mudstones but which may contain clay-sized particles) (Blatt and others, 1980). Today, sedimentary environments that contain muds cover about 60 percent of marine continental shelves and 40 percent of deep ocean basins; continental aquatic environments such as lakes, rivers, estuaries, and deltas also contain high proportions of fine-grained sediments (Hillier, 1995, p. 162). Clearly, clays and clay minerals are critical components of both ancient and modern sedimentary environments.

\section{Diagenesis}

Diagenesis is the in-place alteration of a mineral to more stable forms, excluding surficial alteration (which is weathering); diagenesis occurs, for example, when minerals stable in one depositional environment are exposed to another by burial and compaction.
Common silicate materials such as quartz, feldspars, and volcanic glasses, as well as carbonates, noncrystalline iron oxides, and primary clay minerals, are transformed during diagenesis into more stable clay minerals mainly by dissolution and recrystallization.

The formation of bentonite (beds containing smectite-group clay minerals including montmorillonite) and fuller's earth (a type of clay mineral deposit that has high capacity to absorb water) may occur primarily by diagenesis, although some deposits may also form by hydrothermal processes. Bentonite beds usually form from altered volcanic ash, but other types of rock may also serve as sources. The absorptive properties of bentonites and fuller's earth make them ideal for such diverse uses as drilling mud; foundry-sand bond; binder for pelletizing iron ore and bleaching liquids; absorbents for oil, grease, and animal waste; and carriers for pesticides and fertilizers. Bentonite is also used as a soil liner for environmental containment applications and with polyacrylamide for making paper.

\section{Weathering}

Weathering of rocks and soil is the primary way that clays and clay minerals form at the Earth's surface today. The weathering process involves physical disaggregation and chemical decomposition that change original minerals to clay minerals; weathering is uneven, and many stages of breakdown may be found in the same clay sample. Factors governing rock weathering and soil formation include the initial type of rock, the ratio of water to rock, the temperature, the presence of organisms and organic material, and the amount of time. The types of clay minerals found in weathering rocks strongly control how the weathered rock behaves under various climatic conditions (such as humid-tropical, drytropical, and temperate conditions).

Kaolinite is found in most weathering zones and soil profiles. Montmorillonites, which are chemically more complex than kaolinites, are common in the lower parts of weathering profiles, nearer the rock, where chemistry exerts a strong control on mineralogy. Complex mixed-layer clay minerals (such as illitesmectites) are abundant in clay assemblages that develop from mica-bearing precursor rocks, such as the granite plutons that occur in temperate regions of the Northeastern United States. For example, a large component of soils formed by weathering of granites may consist of metastable muscovite, biotite, and chlorite. These minerals will alter progressively to clay minerals.

\section{Environmental Studies}

Industrial minerals, such as clays, sand, gravel, and crushed stone, are raw materials used for building and maintaining infrastructure, agriculture, and mitigation of environ- mental problems. Because of the many uses for industrial minerals in our society, land management agencies have an increasing need for better geologic and mineralogic data on industrial minerals. The USGS supports studies to understand the geology of these deposits, the surficial environments, and the processes by which these deposits form.

The USGS and industry cooperators are initiating petrologic, mineralogic, and geochemical studies to better determine how economic clay deposits form. A special emphasis of these studies is to characterize the weathering portion of the life cycle of a clay deposit.

Regional data bases (such as the Southeastern United States clay deposit data base) are being developed that contain geologic and geochemical information necessary to establish environmental characteristics that affect the use of clays and clay minerals. Environmental characteristics include the nature and distribution of inorganic contaminants, such as metals and metalloids like arsenic, iron, and lead, in clay-bearing rocks. These environmental factors have the potential to affect the use of clays in natural and industrial applications.

-NORA K. FOLEY

\section{References}

Blatt, H., Middleton, G., and Murray, R. 1980 , Origin of sedimentary rocks (2d ed.): Englewood Cliffs, N.J., PrenticeHall, 766 p.

Hillier, S., 1995, Erosion, sedimentation and sedimentary origin of clays, in Velde, B. ed., Origin and mineralogy of clays: New York, Springer-Verlag, p. 162-219.

Velde, B., 1995, Composition and mineralogy of clay minerals, in Velde, B., ed., Origin and mineralogy of clays: New York, Springer-Verlag, p. 8-42.

\section{For more information, please contact:}

Nora K. Foley

U.S. Geological Survey

954 National Center

Reston, VA 20192

Telephone: (703) 648-6179

E-mail: nfoley@usgs.gov

Data on industrial minerals, including clay and clay mineral deposits, are available from the USGS web site, URL:

http://minerals.er.usgs.gov/minerals/pubs/ commodity/

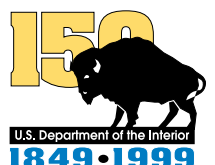

